\author{
Danuta Apanel \\ Zakład Pedagogiki Opiekuńczo-Wychowawczej \\ Instytut Pedagogiki \\ Akademia Pomorska w Stupsku
}

\title{
Organizacja i funkcjonowanie Wyższego Seminarium Duchownego w Koszalinie w latach 1981-2011
}

\begin{abstract}
Danuta Apanel, Organization and Functioning of Higher Theological Seminary in Koszalin in the Years 1981-2011

The study hereby proposed presents the activity of a Catholic college - Higher Theological Seminary in Koszalin in the years 1981-2011. The College came into being thanks to the efforts of Bishop Ignacy Jeż.

In the abovementioned period, the college was administered by five rectors and seven administrative directors. There were 658 students (alumni) and 362 deacons, who took holy orders.

During the six-year program of education, students learned the obligatory, pastoral and theological subjects as well as underwent practical training. The thesis defense took place in the fifth year of studies. The sixth year was intended for practicing and taking religious vows.
\end{abstract}

Keywords: Catholic college, Higher Theological Seminary, research and teaching employee, administrative worker, students-alumni, educational and didactic process

Początki Wyższego Seminarium Duchownego (WSD) w diecezji koszalińsko-kolobrzeskiej. Dnia 6 grudnia 1980 r. wojewoda koszaliński podjął decyzję, na mocy której włączył do planu budownictwa kościelnego na rok 1981 budowę Seminarium Duchownego w Koszalinie ${ }^{1}$.

Plan zabudowy terenu obejmował kościół seminaryjny, trzy domy (główny, salę gimnastyczną, zabudowania gospodarcze), boisko, duży ogród rekreacyjny na terenie $10 \mathrm{ha}^{2}$. Decyzja ta odpowiadała potrzebom diecezji i była spełnieniem długoletnich próśb Kurii Biskupiej, a przede wszystkim wielu starań pierwszego biskupa Ignacego Jeża.

\footnotetext{
${ }^{1}$ Koszalińsko-Kołobrzeskie Wiadomości Diecezjalne, rok VIII, nr 12 (1980), s. 368

${ }^{2}$ Archiwum Diecezji Koszalińsko-Kołobrzeskiej, Segregator Budowa seminarium.
} 
W piśmie Ministra Oświaty i Wychowania Krzysztofa Kruszewskiego czytamy: $\mathrm{Na}$ podstawie art.39 ustawy z dnia 15 lipca 1961 r. o rozwoju oświaty $i$ wychowania (Dz. U. z 1961 r. Nr 32, poz. 160 z późniejszymi zmianami) wyrażam zgodę na otwarcie i prowadzenie Wyższego Seminarium Duchownego dla Diecezji Koszalińsko-Kołobrzeskie i zwalniam je od wymogu świeckości. Niniejsza decyzja jest ostateczna ${ }^{3}$ Taka decyzja, spowodowana wcześniejszymi protestami robotników na Wybrzeżu, otworzyła drogę do erygowania WSD w Koszalinie 4 .

Komitet Budowy WSD diecezji koszalińsko-kołobrzeskiej, w skład którego weszli: ks. bp Tadeusz Werno, ks. Franciszek Pacholski, ks. Stefan Ołów, ks. Piotr Krupa został powołany 27 lutego $1981^{5}$.

Erygowanie i budowa seminarium. Po objęciu urzędu biskupa w nowej diecezji koszalińsko-kołobrzeskiej, pierwszym i najważniejszym zadaniem dla bpa I. Jeża była troska o kształcenie księży, na jednego kapłana bowiem w duszpasterstwie przypadało 3000 wiernych.

Bp I. Jeż wspominał: Każda diecezja ma swoje specyficzne warunki pracy i musi mieć do dyspozycji księdza przygotowanego na te warunki. Nie ukrywamy, że warunki pracy kapłańskiej w tej diecezji sa szczególnie trudne i nie wszyscy księża przechodzacy do pracy duszpasterskiej z innych diecezji wytrzymywali je bez trudności ${ }^{6}$.

W 1974 r. liczba kleryków diecezji koszalińsko-kołobrzeskiej obejmowała 52 osoby. Trzy lata później liczba ta wzrosła do 77. Dane te wskazywały na silną potrzebę wzniesienia własnego budynku seminaryjnego w diecezji.

Dekret podpisany 25 marca 1981 r. przez bpa I. Jeża erygował diecezjalną instytucję seminarium duchownego. W liście pasterskim biskupa koszalińsko-kołobrzeskiego w sprawie budowy Diecezjalnego Seminarium Duchownego z dnia 16 października $1981 \mathrm{r}$. czytamy: Tylko posiadanie własnego seminarium duchownego zapewnić może diecezji przygotowanie dostatecznej ilości kapłanów, którzy potrzebie tej diecezji będa odpowiadali $^{7}$.

Patronem Wyższego Seminarium Duchownego w Koszalinie został św. Jan Kanty (Jan z Kęt), profesor Uniwersytetu Jagiellońskiego w Krakowie. Relikwie tego świętego diecezja otrzymała od Metropolity Krakowskiego, ks. kard. Karola Wojtyły.

Głównym źródłem środków na budowę były ofiary zbierane w całej diecezji od wiernych, jak również pomoc z kościelnych funduszy zagranicznych z Essen i Paderborn w Niemczech. Dyrektorem budowy kompleksu seminaryjnego został ks. Stefan Ołów.

Teren pod budowę budynku przyszłego seminarium w Koszalinie-Wilkowie poświęcił prymas Polski, kardynał Józef Glemp w dniu 27 czerwca 1982 r., natomiast poświęcenie nowego gmachu seminarium miało miejsce 20 października $1984 \mathrm{r}$.

\footnotetext{
${ }^{3}$ Podstawy prawno-organizacyjne Diecezji Koszalińsko-Kołobrzeskiej, ks. K. Dullak, Koszalin 1996, s. 126.

${ }^{4}$ T. Ceynowa, Starania biskupa Ignacego Jeża o utworzenie Wyższego Seminarium Duchownego w Koszalinie, „Studia Koszalińsko-Kołobrzeskie” nr 11, Koszalin 2007, s. 29.

5 Archiwum Diecezji Koszalińsko-Kołobrzeskiej, Segregator Budowa Seminarium.

${ }^{6}$ M. Czerner, Kronika diecezji koszalińsko-kołobrzeskiej, Koszalin 1995, s. 437.

${ }^{7}$ Bp I. Jeż, Listy pasterskie oraz komunikaty do kapłanów i wiernych diecezji w latach 1972-1989, s. 135.
} 
Administracja Wyższego Seminarium Duchownego. Obowiązki dotyczące funkcjonowania seminarium w zakresie spraw ekonomicznych spoczywają na dyrektorze $\mathrm{d} / \mathrm{s}$. administracyjnych.

Diecezjalne seminarium koszalińskie swoje przychody pozyskuje m.in.: z seminaristicum, dwóch zbiórek w roku w każdej parafii, opłat kleryckich, usług hotelarskich, ofiar, dochodów Gospodarstwa Rolnego Semrol w Uliszkach, zagranicznych darowizn.

Na podstawie sprawozdań ekonomicznych należy stwierdzić, że seminarium swoje wydatki przeznacza głównie na: wynagrodzenia pracowników, ubezpieczenia i podatki, funkcjonowanie uczelni, lecznictwo, bibliotekę, wyżywienie, utrzymanie czystości obiektu, kult (paramenta liturgiczne), uzupełnienie wyposażenia (kuchnia, warsztat), naprawy i konserwacje, transport i komunikację, opał i energię elektryczną, inne wydatki ${ }^{8}$.

Tabela 1. Dyrektorzy administracyjni WSD w Koszalinie w latach 1981-2010

\begin{tabular}{|l|c|}
\hline \multicolumn{1}{|c|}{ Imię i nazwisko } & Lata sprawowania funkcji \\
\hline Ks. Tadeusz Nawrot & $1982-1983$ \\
\hline Ks. Jan Ciołek & $1983-1986$ \\
\hline Ks. Józef Pietras & $1986-1993$ \\
\hline Ks. Mariusz Dolny & $1993-2002$ \\
\hline Ks. Waldemar Dębowski & $2002-2005$ \\
\hline Ks. Sławomir Forc & 2005-2008 \\
\hline Ks. Marek Mackiw & od 2008 \\
\hline
\end{tabular}

Źródło: opracowano na podstawie Na Jego chwate, 25 lat Wyższego Seminarium Duchownego w Koszalinie, Koszalin 2006.

Dyrektora administracyjnego w zarządzaniu finansami wspiera pion księgowości. Na stanowisku głównego księgowego w seminarium zatrudnione były dwie osoby: s. Joanna Nitka, Alicja Dunowska-Jakóbczak.

Seminarium jako instytucja zatrudnia również osoby świeckie. W seminaryjnej kuchni i do sprzątania pomieszczeń zatrudnionych było od początku istnienia placówki aż 85 osób, w tym osiem sióstr zakonnych, które pełniły funkcje kucharek.

Na stanowisku palacza i konserwatora pracowało 12 osób, a kierowcy - 7. Jedynym ogrodnikiem pracującym przez okres istnienia seminarium był Andrzej Bielech. W seminarium duchownym istnieje również stanowisko furtianina. Na początku na tym stanowisku zatrudniano osoby świeckie, później furtiankami były - i są do dziś siostry zakonne.

\footnotetext{
${ }^{8}$ Archiwum Kurii Biskupiej Koszalińsko-Kołobrzeskiej, Segregator Seminarium Duchowne S1.
} 
Jedynym świeckim furtianinem był Jan Gołębiowski. Jego następczyniami były w kolejności: s. Anna Babicz (od 1998 r.), s. Wiesława Kołodziej, s. Agnieszka Stachowiak, s. Danuta Gobosz, s. Dorota Wiśniewska.

Miejscem pracy osób świeckich jest również biblioteka seminaryjna, w której pomagają również w ramach swoich obowiązków klerycy. Biblioteka mieści się w budynku Wyższego Seminarium Duchownego. Pierwszymi opiekunami biblioteki byli: ks. Emil Wojtal oraz kolejni księża prefekci studiów. Od 29 września 1995 r. dyrektorem biblioteki był ks. dr Jerzy Chęciński, któremu biblioteka WSD zawdzięcza swój obecny kształt. W 2003 r. dyrektorem Biblioteki WSD został ks. dr Tadeusz Ceynowa, pełniący jednocześnie funkcję dyrektora Archiwum Diecezji Koszalińsko-Kołobrzeskiej i wykładowcy historii Kościoła. Biblioteka Wyższego Seminarium Duchownego w Koszalinie jest członkiem Federacji Bibliotek Kościelnych FIDES. W okresie działania biblioteki pracowało w niej 8 osób świeckich.

W Wyższym Seminarium Duchownym w Koszalinie zatrudniony jest również stomatolog i specjalista $\mathrm{d} / \mathrm{s}$ BHP.

Tabela 2. Stan zatrudnienia w WSD w Koszalinie w okresie istnienia placówki

\begin{tabular}{|l|c|}
\hline \multicolumn{1}{|c|}{ Stanowisko pracy } & $\begin{array}{c}\text { Liczba } \\
\text { zatrudnionych } \\
\text { osób }\end{array}$ \\
\hline Dyrektor administracyjny & 7 \\
\hline Księgowość, administracja & 3 \\
\hline Palacz - konserwator & 12 \\
\hline Kierowca & 7 \\
\hline Pion kuchenny, sprzątaczki, praczki & 85 \\
\hline Biblioteka & 10 \\
\hline Furtianie & 5 \\
\hline Ogrodnik & 1 \\
\hline
\end{tabular}

Źródło: opracowano na podstawie danych z Archiwum WSD w Koszalinie, lata 1982-2010.

Kadra naukowa. Osobą odpowiedzialną za całokształt życia seminaryjnego jest rektor wyznaczany przez biskupa diecezjalnego. Do jego obowiązków należy przede wszystkim troska o formację zgodną z normami i zasadami Kościoła oraz budowanie wspólnoty seminaryjnej. Pierwszym rektorem był bp Piotr Krupa ${ }^{9}$, spełniający swój urząd

${ }^{9}$ Ks. bp Piotr Krupa - urodził się 19 czerwca 1936 r. w Braciejowej (par. św. Mikołaja, diecezja tarnowska), święcenia kapłańskie z rąk bpa Wilhelma Pluty otrzymał w Gorzowie 14 maja 1961 r. Pracował w Gubinie, Świebodzinie, Kołczygłowach oraz Zielonej Górze. W latach 1971-1976 odbył specjalistyczne studia 
w początkowej fazie istnienia seminarium. Jego 5-letnia kadencja zaowocowała przede wszystkim działaniami dotyczącymi budowy seminarium i rozpoczęcia formacji alumnów na terenie diecezji koszalińsko-kołobrzeskiej.

Tabela 3. Rektorzy WSD w Koszalinie w latach 1981-2010

\begin{tabular}{|l|l|}
\hline Lata sprawowania funkcji & Imię i nazwisko Rektora \\
\hline $1981-1986$ & Bp. Piotr Krupa \\
\hline $1986-1993$ & Ks. Marian Subocz ${ }^{10}$ \\
\hline $1993-2003$ & Ks. Zdzisław Kroplewski ${ }^{11}$ \\
\hline $2003-2006$ & Ks. Wacław Łukasz ${ }^{12}$ \\
\hline $2006-$ do dziś & Ks. Dariusz Jarząb ${ }^{13}$ \\
\hline
\end{tabular}

Źródło: opracowano na podstawie danych z Archiwum WSD w Koszalinie.

w zakresie teologii moralnej na Universite des Sciences Humaines w Strasburgu we Francji. Następnie został notariuszem kurii diecezjalnej w Koszalinie (1976-1978). Profesor i rektor seminarium duchownego w Gościkowie-Paradyżu (1977-1980), zwolniony z funkcji rektora na własną prośbę dla kontynuowania studiów specjalistycznych. Po powrocie, rektor seminarium koszalińskiego. Kanonik, teolog koszalińskiej kapituły katedralnej. Biskup tytularny Aquae Albae in Byzacena. Sufragan koszalińsko-kołobrzeski od 18 lutego 1984, sakrę biskupią przyjął 15 kwietnia 1984 r. z rąk kard. Józefa Glempa, prymasa Polski, abpa Jerzego Stroby. Był wikariuszem generalnym diecezj Od 25 marca 1992 r. pełni funkcję sufragana diecezji pelplińskiej.

${ }^{10}$ Ks. Marian Subocz - urodził się 28 sierpnia 1947 r. w Wałczu, święcenia kapłańskie otrzymał 17 czerwca 1973 r. w Lęborku, był wikariuszem w Kołobrzegu, a następnie kapelanem bpa Ignacego Jeża. W latach 1974-1982 odbywał studia na Papieskim Uniwersytecie Salezjańskim w Rzymie na kierunku filologia klasyczna i starochrześcijańska. Był zastępcą sekretarza generalnego KEP, proboszczem w Słupsku (2001-2007), a od 21 czerwca 2007 pełni funkcję dyrektora Caritas Polska. Członek Papieskiej Rady „Cor Unum”.

${ }^{11}$ Ks. Zdzisław Kroplewski - urodzony 17 grudnia 1955 r. w Człuchowie, prezbiterat otrzymał 18 maja 1980 r., wikariusz w Białogardzie. W latach 1982-1986 studia na KUL w Lublinie z psychologii zakończone licencjatem, a w 1990 r. uzyskanie tytułu doktora nauk humanistycznych z zakresu psychologii. Habilitacja na Uniwersytecie Opolskim w zakresie teologii fundamentalnej uzyskana na podstawie rozprawy: Racjonalność rozumowania religijnego: model poznawczy. 1999-2003 - adiunkt na WT UAM w Poznaniu, od 2004 r. dziekan założyciel WT US, profesor US.

${ }^{12}$ Ks. Waclaw Lukasz - urodził się 6 marca 1964 r. w Połczynie Zdroju, prezbiterat otrzymał 28 maja 1989 r., wikariusz w Koszalinie do 1992 r., studia prawnicze na Uniwersytecie Krzyża Świętego w Rzymie w latach 1992-1998, od 1998 r. sędzia Sądu Biskupiego w Koszalinie, adiunkt katedry prawa kanonicznego WT UAM, a następnie WT US, proboszcz w Słupsku (2006-2007), od 2007 kanclerz kurii biskupiej w Koszalinie.

${ }^{13}$ Ks. Dariusz Jastrząb - urodzony 14 stycznia 1960 r. w Słupsku, dr teologii, absolwent Papieskiego Uniwersytetu Laterańskiego oraz Akademii Teologii Moralnej Alfonsiana. Praca doktorska dotyczyła moralnych aspektów twórczości F. Dostojewskiego: Chrystus, Bóg-Człowiek jako wyzwolenie tragicznej antynomii dobra i zła w człowieku Dostojewskiego. Święcenia kapłańskie otrzymał 25 maja 1986 r. z rąk bpa Tadeusza Werno. 
Strukturę seminarium duchownego i jego wszelkie działania określa biskup diecezjalny. Jego zadaniem jest czuwać nad zachowywaniem wszelkich zasad, regulaminów i przepisów, ustalonych przez Stolicę Apostolską. Do kompetencji biskupa należy także wybór wykładowców, profesorów, ojców duchownych i wychowawców.

Tabela 4. Wyższa Kadra WSD w Koszalinie w latach 1980-2005

\begin{tabular}{|c|c|c|}
\hline Funkcja & Imię i nazwisko & Lata pracy \\
\hline Wicedyrektorzy WSD & $\begin{array}{l}\text { ks. Marian Subocz } \\
\text { ks. Antoni Kloska } \\
\text { ks. Zdzisław Kroplewski } \\
\text { ks. Romuald Jankiewicz } \\
\text { ks. Jacek Lewiński }\end{array}$ & $\begin{array}{l}1983-1986 \\
1986-1992 \\
1992-1993 \\
1997-2004 \\
\text { od } 2004 \\
\end{array}$ \\
\hline Prefekci studiów & $\begin{array}{l}\text { ks. Jan Turkiel } \\
\text { ks. Marek Żejmo } \\
\text { ks. Zdzisław Kroplewski } \\
\text { ks. Romuald Jankiewicz }\end{array}$ & $\begin{array}{l}1984-1987 \\
1987-1990 \\
1990-1992 \\
1993-1997 \\
\end{array}$ \\
\hline Prefekci & $\begin{array}{l}\text { ks. Marian Subocz } \\
\text { ks. Lech Nowak } \\
\text { ks. Antoni Kloska } \\
\text { ks. Józef Turkiel } \\
\text { ks. Andrzej Korpusik } \\
\text { ks. Tadeusz Wilk } \\
\text { ks. Zygmunt Czaja } \\
\text { ks. Krzysztof Zadarko } \\
\text { ks. Stanisław Łącki } \\
\text { ks. Dariusz Jastrząb } \\
\text { ks. Krzysztof Kowal } \\
\text { ks. Mariusz Kołaciński } \\
\text { ks. Wacław Łukasz } \\
\text { ks. Jacek Lewiński } \\
\text { ks. Janusz Bujak } \\
\text { ks. Eugeniusz Kaczor } \\
\text { ks. Leszek Szurek }\end{array}$ & $\begin{array}{c}1982-1983 \\
1984-1988 \\
1984-1986 \\
1985-1987 \\
1987-1990 \\
1988-1993 \\
1989-1991 \\
1991-1994 \\
1993-1997 \\
1994-1995 \\
1994-2000 \\
1995-2000 \\
1998-2003 \\
2000-2004 \\
2000-2005 \\
\text { od } 2004 \\
\text { od } 2004 \\
\end{array}$ \\
\hline Ojcowie duchowni & $\begin{array}{l}\text { o. Ludwik Chodziło CM } \\
\text { ks. Mateusz Krzywicki } \\
\text { ks. Jan Nowak } \\
\text { ks. Józef Kwieciński } \\
\text { ks. Dariusz Jastrząb } \\
\text { ks. Antoni Badura } \\
\text { ks. Andrzej Hryckowian }\end{array}$ & $\begin{array}{c}1984-1993 \\
1982-1984,1987-1987 \\
1988-1996 \\
1993-1995 \\
1995-2003 \\
\text { od } 1996 \\
\text { od } 2003 \\
\end{array}$ \\
\hline
\end{tabular}

Źródło: opracowano na podstawie Na Jego Chwałe..., album WSD, ss. 32-35 ${ }^{14}$

Kadra naukowa w seminarium podlega władzy biskupa, który czuwa nad jej kształceniem. Biskup powinien starać się o to, aby alumnów uzdolnionych i ugruntowanych w cnocie kierować do instytutów, wydziatów lub uniwersytetów dla zdobycia specjali-

\footnotetext{
${ }^{14}$ Na Jego chwate, 25 lat Wyższego Seminarium Duchownego w Koszalinie, Koszalin 2006, ss. 32-35.
} 
stycznego wykształcenia w naukach teologicznych lub innych, uznanych za przydatne dla potrzeb diecezji $i^{15}$. Z jego postanowienia księża udają się na studia doktoranckie w Polsce i za granicę. Głównymi ośrodkami kształcenia są m.in.: Uniwersytet im. Kard. Stefana Wyszyńskiego oraz Katolicki Uniwersytet Lubelski. Uczelniami zagranicznymi są uniwersytety we Włoszech, Francji, Niemczech i Szwajcarii.

Kadrę WSD w Koszalinie stanowią również księża pełniący funkcję wicedyrektorów, prefektów studiów oraz ojcowie duchowni, a także osoby świeckie.

Seminarium jako uczelnia zatrudnia także księży, którzy pełnią funkcje moderatorów i wychowawców. Księża moderatorzy i wychowawcy uczestniczą w zjazdach organizowanych przez Wyższe Seminaria Duchowne na terenie Polski i Niemiec. Grono wykładowców uczestniczy w Kongresach Teologów Polskich.

Ojcowie duchowni i spowiednicy powinni posiadać kwalifikacje, które określają ich jako mistrzów życia wewnętrznego.

Profesorowie seminarium duchownego powinni być przygotowani do swoich zajęć przez praktykę pedagogiczno-pastoralną, specjalistyczne studia, uwieńczone stopniem naukowym: habilitacja, doktorat. W wyjątkowych przypadkach mogą posiadać stopień licencjata. Do ich zadań należy przygotowanie alumnów do kapłaństwa, wyposażenie ich w odpowiednią wiedzę i umiejętności związane z posługą duszpasterską.

Alumni. Do wyższych seminariów duchownych przyjmowani są tylko kandydaci, którzy ukończyli szkołę średnią i mają uprawnienia do podjęcia studiów wyższych, a nastawienie ich woli daje nadzieję, że na zawsze oddadzą się służbie Kościoła.

Kandydaci ubiegający się o przyjęcie do wyższych seminariów duchownych powinni przedłożyć rektorom tych uczelni następujące dokumenty: prośbę o przyjęcie z podaniem motywów swojej decyzji, świadectwo sakramentu chrztu i bierzmowania, wyciąg z aktu urodzenia, świadectwo nauki religii, opinie proboszcza i katechety, świadectwo lekarza wskazanego przez seminarium o stanie zdrowia fizycznego i psychicznego, fotografie formatu legitymacyjnego.

Podczas rozmowy z kandydatami rektorzy badają ich intencje dotyczące wyboru kapłaństwa. W celu podjęcia właściwej decyzji mogą zasięgać opinii innych osób.

Podczas pierwszego roku studiów klerycy badają swoje powołanie. Odbywają się pierwsze praktyki religijne w ramach wspólnoty rocznikowej, w osobnej kaplicy, pod przewodnictwem ojca duchowego i księdza prefekta. W tym okresie alumni muszą wkładać dużo wysiłku w rozwój cech osobowościowych, przeżywania i rozumienia własnych uczuć, panowania nad nimi, empatii, odpowiedzialności za swoje obowiązki, systematyczności, samodyscypliny. Podczas drugiego i trzeciego roku studiów alumni kontynuują pracę nad rozwojem własnej osobowości i charakteru, pogłębiają swoją ewangelizację, angażują się w życie seminaryjne przez pełnienie różnego rodzaju funkcji na rzecz wspólnoty.

Roczniki IV, V, VI poza pełnym zaangażowaniem w życie seminaryjne, podejmują działania duszpasterskie. Uczą się również zachowania równowagi między działaniami zewnętrznymi a życiem duchowym.

${ }^{15}$ Dekret o formacji kapłańskiej, nr 18. 
W trakcie trzeciego roku studiów klerycy przyjmują sutannę i otrzymują posługę lektoratu, czyli konkretne zadanie we wspólnocie Kościoła, w trakcie czwartego roku otrzymują pozwolenie na udzielanie Komunii Świętej. Alumni piątego roku przez obrzęd kandydatury składają publiczne oświadczenie o swojej zdecydowanej woli poświecenia się kapłaństwu, a z końcem roku akademickiego przyjmują święcenia diakonatu.

Wyższe Seminarium Duchowne w Koszalinie wykształciło wielu kapłanów na potrzeby diecezji koszalińsko-kołobrzeskiej. Jednak nie wszyscy alumni przyjęli świecenia kapłańskie i nie wszyscy przetrwali trudy nauki.

Studia w WSD są trudne, wymagają wielu wyrzeczeń, odpowiedniej postawy, moralności. Wielu alumnów nie potrafi podołać rygorom wiary, celibatu, formacji, dlatego odchodzi w trakcie nauki, często po święceniach diakońskich lub przed nimi, a nawet po ukończeniu ostatniego roku. Niektórzy alumni przebywają na urlopach dziekańskich, co wpływa na zmiany terminów ich ukończenia. Abiturienci tej uczelni często podejmują studia doktoranckie na uczelniach w Polsce lub poza jej granicami.

Tabela 6. Stan alumnów pierwszego roku formacji WSD w Koszalinie w latach 1980-2006 i liczba udzielonych diakonom świeceń kapłańskich

\begin{tabular}{|c|c|c|}
\hline Rok & Liczba alumnów & $\begin{array}{c}\text { Udzielone święcenia } \\
\text { kapłańskie }\end{array}$ \\
\hline 1981 & 13 & 10 \\
\hline 1982 & 28 & 12 \\
\hline 1983 & 21 & 7 \\
\hline 1984 & 21 & 8 \\
\hline 1985 & 26 & 16 \\
\hline 1986 & 27 & 17 \\
\hline 1987 & 40 & 13 \\
\hline 1988 & 22 & 23 \\
\hline 1989 & 26 & 23 \\
\hline 1990 & 25 & 16 \\
\hline 1991 & 19 & 20 \\
\hline 1992 & 30 & 18 \\
\hline 1993 & 25 & 17 \\
\hline 1994 & 28 & 10 \\
\hline 1995 & 29 & 15 \\
\hline 1996 & 26 & 11 \\
\hline
\end{tabular}




\begin{tabular}{|l|l|l|}
\hline 1997 & 26 & 13 \\
\hline 1998 & 29 & 13 \\
\hline 1999 & 22 & 10 \\
\hline 2000 & 22 & 17 \\
\hline 2001 & 30 & 15 \\
\hline 2002 & 20 & 11 \\
\hline 2003 & 27 & 14 \\
\hline 2004 & 29 & 9 \\
\hline 2005 & 21 & 12 \\
\hline 2006 & 26 & 12 \\
\hline
\end{tabular}

Źródło: opracowano na podstawie danych z Archiwum Wyższego Seminarium Duchownego w Koszalinie, Rekrutacja

Studenci kończący naukę w Wyższym Seminarium Duchownym otrzymują stopień magistra, co daje im możliwość kontynuacji nauki na studiach podyplomowych, doktoranckich.

W WSD w Koszalinie klerycy i członkowie formacji seminaryjnej związani są z wyznaczonymi funkcjami dotyczącymi życia codziennego i funkcjonowania seminarium. Zaangażowanie ma wymiar społeczny oraz religijny, uczy odpowiedzialności za powierzone zadania i wykonywania ich w duchu chrześcijańskim.

Ważną rolę spełnia w formacji rada klerycka, w skład której wchodzą dziekan, wicedziekan kleryków, duktorzy i po jednym alumnie każdego rocznika:

- dziekan kleryków - kleryk V roku, obejmuje funkcję po powrocie z uroczystości Wszystkich Świętych,

- wicedziekan - wybierany przez alumnów roku IV,

- duktorzy - wybierani na początku roku akademickiego, spełniają swoje funkcje w ramach poszczególnych roczników,

- ceremoniarze - kierujący czynnościami liturgicznymi,

- zakrystianie - troszczą się o kaplicę i zakrystie, dbają o sprzęt liturgiczny, bieliznę kościelną,

- bibliotekarze - spełniają funkcje pod kierunkiem księdza dyrektora biblioteki,

- infirmiarze - opiekujący się chorymi alumnami, dbają o infirmerię i aptekę seminaryjną, współpracują z służbą medyczną,

- gospodarczy - wyznaczają i koordynują prace na terenie uczelni, pracują pod kierunkiem księdza dyrektora administracyjnego i księży prefektów,

- kronikarz, notujący systematycznie wszystkie ważniejsze wydarzenia z życia Wyższego Seminarium Duchownego w Koszalinie w kronice i dokumentuje je za pomocą fotografii i innych materiałów. 
Oprócz wyżej wymienionych funkcji studenci seminarium pełnią inne zadania, związane z prowadzeniem formacji. Należą do nich organiści, furtianie, księgarze, dekoratorzy, kuratorzy ds. sportu i kultury i inni.

Każdy dzień pobytu alumnów w seminarium przebiega według ustalonego porządku:

5.45 - pobudka,

6.15 - Jutrznia, medytacja,

7.10 - Msza Święta, śniadanie,

8.30-12.45 - wykłady,

12.55 - rachunek sumienia, Anioł Pański, obiad, rekreacja,

14.45 - 16.00 - studium,

$16.00-16.30$ - podwieczorek,

$16.30-17.45$ - studium,

17.45 - 18.00 - przerwa,

18.00 - 18.30 - czytanie duchowe,

18.30 - Anioł Pański (w refektarzu), kolacja, rekreacja,

20.00 - Silentium religiosum,

20.00 - 21.00 - Nieszpory, możliwość adoracji Najświętszego Sakramentu,

22.00 - spoczynek nocny.

W okresie świątecznym i w niedziele:

6.45 - pobudka,

7.15 - Jutrznia, medytacja,

8.00 - śniadanie,

9.00 - Msza Święta,

12.25 - rachunek sumienia, Anioł Pański, obiad, rekreacja,

18.00 - Nieszpory,

18.30 - kolacja, rekreacja,

22.30 spoczynek nocny.

Jak wynika z rozkładu dnia, alumni każdy powszedni dzień mają wypełniony modlitwą, nauką. W wolnych chwilach mogą oddać się zajęciom rekreacyjnym oraz rozwijać swoje zainteresowania.

\section{Podsumowanie}

Koszalińskie Wyższe Seminarium Duchowne powstało 25 marca 1981 r., ale pierwsi klerycy wprowadzili się do niego dopiero po wybudowaniu budynku, w którym studenci mogli zamieszkać.

W dwudziestopięcioletniej historii uczelnią kierowało pięciu rektorów i siedmiu dyrektorów administracyjnych. Nad alumnami sprawowało opiekę 10 ojców duchownych. W tym okresie naukę pobierało 658 alumnów, a świecenia kapłańskie złożyło 362 diakonów.

Pierwsi studenci uzyskiwali stopień magistra na Uniwersytecie im. Adama Mickiewicza w Poznaniu, obecnie WSD w Koszalinie stanowi filię Wydziału Teologicznego Uni- 
wersytetu w Szczecinie, którego dziekanem jest były rektor seminarium, ks. Zdzisław Kroplewski.

Wyższe Seminarium Duchowne w Koszalinie jako uczelnia katolicka finansowana jest również ze składek wiernych z Diecezji Koszalińsko-Kołobrzeskiej, datków sponsorów, Przyjaciół Rodziny WSD.

Alumni podczas sześcioletniej edukacji uczą się przedmiotów obowiązkowych, przedmiotów pastoralnych, teologicznych, odbywają również praktyki. Obrona pracy dyplomowej odbywa się po piątym roku. Szósty rok to czas praktyki prezbiteriańskiej i złożenia ślubów kapłańskich.

Zdaniem rektora ks. dra Dariusza Jastrzębia we współczesnych czasach, w seminariach duchownych amplituda koniecznych do przeprowadzenia przemyśleń rozciaga się pomiędzy nieustannym diagnozowaniem zmian, jakie zachodza $w$ mentalności młodego pokolenia, a ustaleniem form obowiazujacych $w$ procesie wprowadzania $w$ tajemnice powolania ${ }^{16}$.

\section{Bibliografia}

Źródła archiwalne:

Archiwum Diecezji Koszalińsko-Kołobrzeskiej:

Kronika seminaryjna, 3.01.1980-17.02.1992.

Kroniki seminaryjne z lat $1980-2006$.

Segregator Afiliacja WSD w Koszalinie do PWT w Poznaniu, Regulamin i Statut Wydziału Teologicznego Uniwersytetu im. Adama Mickiewicza w Poznaniu, Preambuła.

Segregator - Budowa seminarium.

Segregator Korespondencja wysyłana do czerwca 1995 r.

Segregator - Nominacje seminaryjne.

Segregator - Praktyki kleryckie, Zasady praktyki duszpasterskiej /Diakoni/.

Segregator-Siostry.

Archiwum Kurii Biskupiej Koszalińsko-Kołobrzeskiej:

Segregator Seminarium Duchowne S1.

Źródła drukowane:

Informator o zakonach i seminariach duchownych $w$ Polsce, (red.) o. E. Osiecki SVD, Pieniężno 1982.

Kodeks Prawa Kanonicznego, Poznań 2008.

Koszalińsko-Kołobrzeskie Wiadomości Diecezjalne, rok II, nr 6 (1974).

Koszalińsko-Kołobrzeskie Wiadomości Diecezjalne, rok VI, nr 9-10 (1978).

Koszalińsko-Kołobrzeskie Wiadomości Diecezjalne, rok VIII, nr 12 (1980).

Koszalińsko-Kołobrzeskie Wiadomości Diecezjalne, rok IX, nr 12 (1981).

I Synod Diecezji Koszalińsko-Kołobrzeskiej, Koszalin 1986-1990.

\footnotetext{
${ }^{16}$ D. Jastrząb, O rozmowach z klerykiem, w: Pastorem, zeszyt 4/41, 2008, s. 45.
} 
Kronika Wyższego Seminarium Duchownego w Koszalinie 1980-2011, Koszalin 2011.

Podstawy prawno-organizacyjne Diecezji Koszalińsko-Kołobrzeskiej, ks. K. Dullak, Koszalin 1996.

Schematyzm Diecezji Koszalińsko-Kołobrzeskiej 1998, Kuria Biskupia Koszalińsko-Kołobrzeska, Koszalin 1998.

Sobór Watykański II Konstytucje, Dekrety, Deklaracje, Poznań 2002.

Zasady formacji kapłańskiej, (red.) ks. Ireneusz Skubiś, Częstochowa 1999.

Zasady życia seminaryjnego, WSD Diecezji Koszalińsko-Kołobrzeskiej, rok akademicki św. Pawła 2008/2009.

Opracowania:

Banaszak M. ks., Historia Kościoła katolickiego, Czasy najnowsze, t. 4, Warszawa 1992.

Banaszak M. ks., Historia Kościoła katolickiego, Średniowiecze, t. 2, Warszawa 1987.

Banaszak M. ks., Historia Kościoła katolickiego, Czasy nowożytne 1517-1758, t. 3, Warszawa 1989.

Bończa-Bystrzycki L. ks., Historia diecezji koszalińsko-kołobrzeskiej 1972-2005, w: Kościót rzymskokatolicki na Pomorzu Zachodnim i Ziemi Lubuskiej w latach 1945-2005, Szczecin 2005.

Czerner M., Kronika diecezji koszalińsko-kołobrzeskiej, Koszalin 1995.

Encyklopedia chrześcijaństwa, Historia i wspótczesność 2000 lat nadziei, (red.) ks. H. Witczyk, Kielce 2000.

Historia chrześcijaństwa, (red.) A. Hastings, Warszawa 2002.

Jeż I. Bp, Listy pasterskie oraz komunikaty do kapłanów i wiernych diecezji w latach 1972-1989.

Kościót katolicki w Polsce 1918-1990, (red.) dr L. Adamczuk, ks. prof. W. Zdaniewicz, Warszawa 1991.

Kumor B. ks., Ustrój i organizacja Kościoła polskiego w okresie niewoli narodowej 1772-1918, Kraków 1980.

Laskowski L., Diecezja Koszalińsko-Kołobrzeska w latach 1972-2002, Koszalin 2002.

Lemaitre N., Quinson M-T., Sot V., Stownik kultury chrześcijańskiej, Warszawa 1997.

Na Jego chwate, 25 lat Wyższego Seminarium Duchownego w Koszalinie, Koszalin 2006.

North J.B., Kontrreformacja katolicka i wojna trzydziestoletnia, w: Historia Kościoła, Warszawa 2000

Nowe diecezje Kościoła katolickiego w Polsce, (red.) L. Adamczuk, ks. Witold Zdaniewicz Warszawa 1994.

Radość z nadziei, W 25-lecie postugi biskupiej ordynariusza koszalińsko-kołobrzeskiego, WSD Diecezji Koszalińsko-Kołobrzeskiej, Koszalin 1985.

Schatz K., Sobory powszechne. Punkty zwrotne w historii Kościoła, Kraków 2002.

Tomczak R. ks. (red.), Diecezjalne Wyższe Seminarium Duchowne Gorzów Wlkp - Paradyż 19471997. Księga jubileuszowa, Paradyż 1997.

Artykuły i rozprawy w wydawnictwach ciągłych:

Ceynowa T., „, Starania biskupa Ignacego Jeża o utworzenie Wyższego Seminarium Duchownego w Koszalinie”, „Studia Koszalińsko-Kołobrzeskie”, nr 11, Koszalin 2007, s. $23-32$.

Jastrząb D., O rozmowach z klerykiem, ,Pastorem”, zeszyt 4/41, 2008, s. 43-46.

Starowieyski M., Seminaria, co dalej?, „W drodze”, 1991, s. 90-96. 